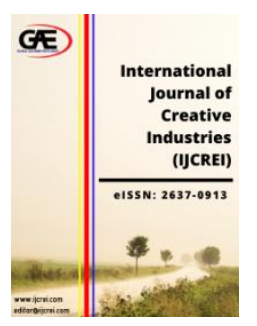

\author{
International Journal of Creative \\ Industries (IJCREI) \\ Journal Website: http://ijcrei.com/ \\ eISSN: 2637-0913
}

\title{
STRATEGIC PARTNERSHIP MODEL ON CREATIVE ECONOMY DEVELOPMENT IN INDONESIA BASED ON LOCAL ARTS AND CULTURE IN BANDUNG REGENCY
}

\author{
Hilmiana $^{1}$, Imas Soemaryani ${ }^{2}$, Joeliaty ${ }^{3}$ \\ $1 \quad$ Faculty of Economics and Business, Universitas Padjadjaran, Indonesia \\ Email: hilmiana@unpad.ac.id \\ 2 Faculty of Economics and Business, Universitas Padjadjaran, Indonesia \\ Email: imas.soemaryani@unpad.ac.id \\ 3 Faculty of Economics and Business, Universitas Padjadjaran, Indonesia \\ Email: joeliaty@unpad.ac.id
}

\section{Article Info:}

\section{Article history:}

Received date:24.12.2019

Revised date: 02.01.2020

Accepted date: 13.01 .2020

Published date: 10.03.2020

\section{To cite this document:}

Hilmiana., Soemaryani, I., \& Joeliaty. (2020). Strategic Partnership Model on Creative Economy Development in Indonesia Based on Local Arts and Culture in Bandung Regency. International Journal of Creative Industries, 2 (3), 01-14.

DOI: $10.35631 /$ IJCREI.23001.

\begin{abstract}
:
In 2016, the Indonesian economy grew by $5.02 \%$. It was the third-largest growth after China and India among the G20 countries. The creative economy itself contributed 852 trillion rupiahs or $7.38 \%$ to that GDP. It is a remarkable achievement of the economy of Indonesia. Achieving higher performance requires collaborations among all parties in quadruple helix, contributing to the establishment of partnership patterns. They should work based on their task, principle, function, and capacity in synergy. Hence, it is necessary to set effective guidelines (manual) or ecosystem development of the creative economy at a regional level. Besides, it is a prerequisite to establishing partnership programs between government and creative communities through the program of 3Cs (Connect - Collaborate - Commerce). The problem examined in this study relates to the development of the creative economy based on local arts and culture in Bandung Regency. The main objective of this study is to construct the strategic partnership model which can impact the creative economy sector in Bandung Regency, based on local arts and culture. This research uses a focus group discussion (FGD) technique involving all essential parties and interviews with stakeholders in regional work units who have the authority to make decisions related to the development of the creative economy. FGD and interview generate accountable information related to mapping potential of the creative economy, SWOT analysis and available partnership programs for the development of the creative economy based on local arts and culture, and description of partnership system between related parties in the quadruple helix. Therefore, it is necessary to establish guidelines or document which can be used in the policymaking. Besides, FGD and interview result in the concept of a government partnership program with creative communities through the program of 3Cs (Connect - Collaborate Commerce). This research is expected to encourage many regions to connect,
\end{abstract}


collaborate, and commerce so they can create new programs that will be conducted together with their supporting partners. The results of this study show that the role of government in the quadruple helix is $60 \%$ in 2016 , decreasing to $10 \%$ in 2019 . The decreasing government role is also accompanied by the increasing role of creative entrepreneurs each year (55 percent in 2019). It shows that the development of the creative economy is becoming more independent every year.

Keywords:

Strategic Partnership Model, Creative Economy Based on Local Arts and Culture

\section{Introduction}

In this ever-changing and globalized era, innovation and creativity have gained more importance for the economy. An organization or economy promoting innovation will be able to produce much higher income and create better stability (Pol, 2005). The idea of the creative economy has been developing as an effort to focus on the creativity role, which plays a significant force in the contemporary economy. Creativity can become a part of a much broader development process (Hidayat \& Asmara, 2017). This principle can be implemented in both developed and developing countries. This policy is a part of economic policies offering and providing opportunities to the emerging nations because it will accelerate economic development (UNESCO \& UNDP, 2013) (UNCTAD \& UNDP, 2008).

The creative economy has a close relationship with the creative industry and culture. The importance of these two aspects has been significantly growing in the past years. Presently, the culture and creative industry support economic growth and global demand supported by emerging economies. That definition is not only in line with the cultural domain but also with goods and services related to the culture which act like a new and robust sector known as cultural area (Boccella \& Salerno, 2016). According to UNESCO, the essential pillar of the economy in the post-modern industrial era is the creative and cultural industries. These include the creation of goods and intangible services related to culture such as movies, printings, and handicrafts (UNESCO, n.d.)

The creative economy is considered as the one with various local paths. Most of these paths can be found at the sub-national level, i.e., in cities and regions of developing nations (UNESCO \& UNDP, 2013). Since the emergence of the creative industry in the 2000s, the local policy instrument of Bandung city has been embracing the creative economy. Based on the data of BEKRAF (Badan Ekonomi Kreatif), the creative economy has a positive trend every year. Since the previous decades, small and medium enterprises (SMEs) have been able to survive and contribute to the Indonesian economy (Akira et al., 2011; Kuswanto, Rosli, \& Kader, 2012). In 2010-2015, the contribution of the creative industry to the GDP (Gross Domestic Product) of Indonesia grew from 525.96 trillion rupiahs to 852.24 trillion rupiahs. In 2015 , this number increased by $4.38 \%$ from the previous year. In that year, the contribution of the creative economy was around $7.38 \%$ to the GDP of Indonesia, contributed primarily by culinary, fashion, and handicraft sectors. This phenomenon also influenced the labor sector, where 16.06 million people were actively employed in the sector of the creative economy. This number grew $5.22 \%$ from the previous year (2014), i.e., 15.46 million people (Kreatif \& Outlook, 2019). 
The creative industry is expected to contribute significantly to the economy of Indonesia because it generates additional state revenues in the short and long terms. Besides, the creative industry opens more employment, reduces poverty, improves export competitiveness, and strengthens national cultural identity as a tool of 'soft-power' diplomacy in the global environment. It is also believed that the creative economy has a multiplier effect on stimulating real sectors and other industries. There are three sectors which employ most labor forces, namely agro-based industries, (38.8 million workers or 43.7\%), trading and hotel industries (22.2 million workers or $25.0 \%$ ), and service industry (9.4 million workers or $10.5 \%$ ) (Kementerian Kesejahteraan Publik, 2007; Rosli, Raflis, \& Omar, 2012). In agro-based industries, most SMEs involve in simple manufacturing activities such as creating wood products (furniture), textile, garment, shoes, food, and beverages because most of the materials come from the agricultural sector (Tambunan, 2000; Rosli et al., 2012).

From that explanation, we can see that there is a promising opportunity for the creative economy to flourish in Indonesian provinces or cities because it will contribute to the local revenues (PAD). A problem that may appear is the lack of involvement among stakeholders to thoughtfully develop and maintain this sector so the ecosystem of the creative economy will be firm. Besides, the decisions that have been made are not based on potential mapping, which considers strengths, weaknesses, opportunities, and threats. The results of this present study are expected to provide a portrayal of those aspects. Therefore, these can assist all stakeholders in the creation of a conducive creative economy so they will finally obtain considerable benefits.

\section{Literature Review}

\section{The Helix Approach}

In recent decades, a rigid division of employment between universities and business in some countries has begun to fade. This academic revolution integrating missions for economic and social development has shifted traditional teaching and research universities into entrepreneurial universities (Colapinto \& Porlezza, 2012). The Triple Helix model is a development strategy based on collaboration among universities, industry, and government, where universities play a significant role in innovation (Etzkowitz \& Leydesdorff, 2000) (Etzkowitz \& Zhou, 2007). This model considers only three helices that intertwine with each other and generates a national innovation system limited to a top-down approach, namely, universities, industry, and government. Subsequently, Carayannis and Campbell (2009) proposed to add a fourth helix identified as "media-based and culture-based public" and "civil society." This later model introduces and incorporates the bottom-up approach (Carayannis, Goletsis, \& Grigoroudis, 2018). This model is called the quadruple helix (four-helix) which adds the "public" or more precisely the "media-based and culture-based public" to government, universities (higher education), and the industry as found in the previous model. The fourth helix in the quadruple helix is associated with 'media,' 'creative industries,' 'culture,' 'values,' 'lifestyles,' and the idea of the 'creative class' (a terminology proposed by Richard Florida, 2004); (Carayannis \& Campbell, 2010). The quadruple helix model is originally conceptualized by Elias Carayannis and David Campbell as a spiral with four strands (Schütz, Heidingsfelder, \& Schraudner, 2019). Finally, the Quadruple Helix model consists of four elements, namely academia, industry, government, and society. They have significant roles in achieving the shared innovation goals and contribute to the socio-economic progress of the regions (Halibas, Sibayan, \& Maata, 2017). 
Furthermore, the Penta Helix was proposed, and it is a socio-economic development model that drives a knowledge economy to pursue innovation and entrepreneurship through collaboration and beneficial partnership among the academia, government, industry, NGOs and civic sectors of the society, and the social entrepreneurs (REPEC, 2012); (Halibas et al., 2017). The Penta Helix model has its roots in the Triple Helix (Etzkowitz \& Leydesdorff, 2000) where a tri-lateral network of academia, industries, and government combine to take advantage of the innovative research projects that are cultured within educational institutions and transform these projects to viable commercial products or services. NGOs, civil society, and the social entrepreneurs were added to the Penta Helix model.

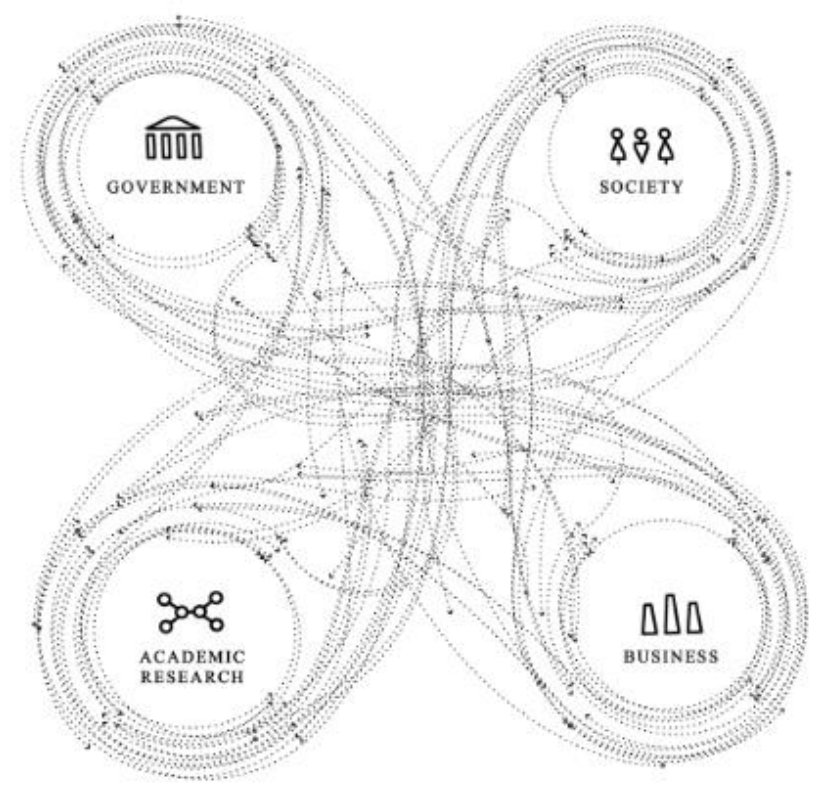

Figure 1. The Quadruple Helix Model Adapted from Fraunhofer (2016), Initially

Developed by Carayannis and Campbell (2009)

Source: (Schütz et al., 2019)

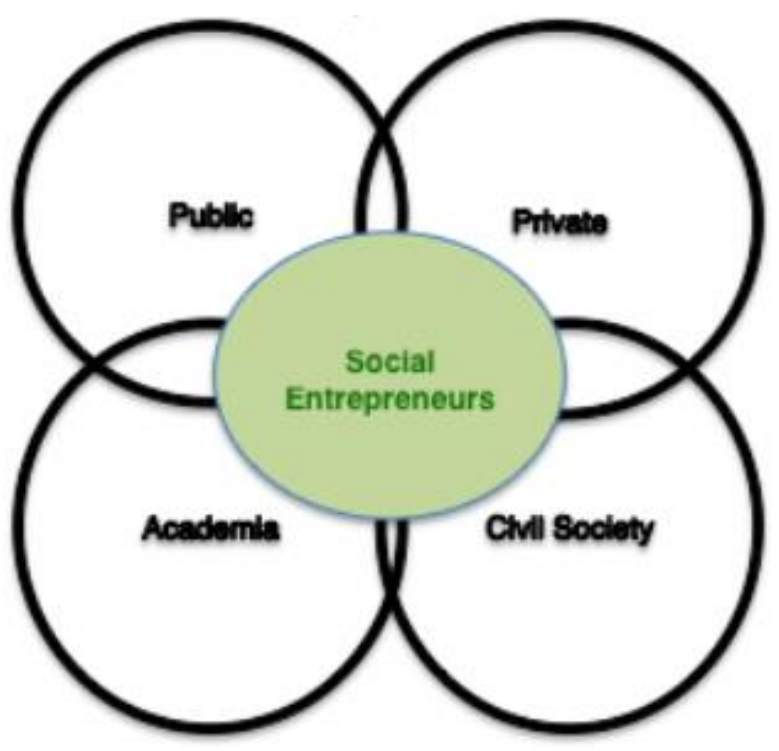

Figure 2. The Penta Helix

Source : (Calzada, 2016) 
Each helix plays a different role where academia is the one with the central concern of finding satisfaction in cultivating arts and science over the metaphysical musings, and not about to seek practical goals. The business side has a role in the framework of an exchange economy (economic exchange relations) as well as the transformation of creativity into economic value in the digital world. The government, on the other hand, has a role in terms of the mechanism of awarding of the intensive course, a conducive business climate control, educational, as well as referrals to society and the world of private sector to support the development of the digital industry (Effendi, Syukri, Subiyanto, \& Utdityasan, 2016). Society primarily engages in social and economic development through active participation in regional development programs (Halibas et al., 2017).

\section{Methods}

The research method used in this study is a qualitative descriptive method. In the social sciences, a qualitative research method is developed to allow researchers to analyze social and cultural phenomena by observing the emotions, thoughts, behaviors, and beliefs of the mass society. The sources of qualitative data include observation, interviews, questionnaires, and documents (Ramesh Babu, 2008). Data used in this study is collected through FGD (Focus Group Discussion) and interviews with all related parties. Bandung Regency is selected as the scope of this research because it has many creative economic centers, and its local government agencies (SKPD) provide supports in the development of the creative economy.

This present study implements a SWOT analysis incorporating Internal Strategic Factors Summary (IFAS) and External strategic Factors Summary (EFAS). The steps to create EFAS and IFAS tables are shown as follows (Rufaidah, 2014):

a. Identify and arrange 5 to 10 items for each strength, weakness, opportunity, and threat in column 1

b. Give each item a value starting from 1.0 (most important) to 0.0 (most unimportant) in column 2

c. Give a rating for each factor starting from 5 (very good) to 1 (very bad), based on management response to each factor. This rating goes in column 3

d. Multiply the value of each factor in column 2 with the rating in column 3 in order to get scores in column 4

e. Use column 5 to show how the selected factor is chosen and how the evaluation works and is done

f. Add all the scores in column 4 to obtain a total score of the company

Total scores show how well a company response to both the internal and external strategic factors. Total scores range from 5.0 (very good) to 1.0 (very bad) with 3.0 as an average score.

\section{Results and Findings}

\section{Potential Mapping of Creative Economy}

\section{Publishing and Printing}

The creative activities related to publishing and printing include content writing, book, newspaper, and digital content. This sector also includes the publication of stamp, paper money, tickets, and others. Graphs such as posters, paintings, and recordings of micro-film are also considered as the activities of publishing and printing in the creative economy. The development of this sector in Bandung Regency has been well developed. 


\section{Crafts}

Crafts are products made by craftsmen, and these are considered as creative activities because they need creative thinking processes, starting from the design to the finished product. Based on this research, Bandung Regency has a developed craft sector. Various handicrafts are made by the community, such as toys, crafts, and fashion. Baleendah is one of the sub-districts that has an advanced painting industry, attracting the attention of foreign tourists.

\section{Advertising}

The creative activities related to advertising services consist of creative processes, production, and output of advertisements such as pamphlets, brochures, posters, and ads. Ads in Bandung Regency can be seen on highways and certain places that are considered promising. There are many advertising media and brochures distributed in many places. The types of ads that can be seen in Bandung Regency include billboards, led screens, and stickers.

\section{Art Exhibitions}

The creative activities related to art exhibitions or performances include ballet performances, traditional dances, modern dances, theater, classical music, theater music, opera, and cultural tourism. Various traditional arts such as Sisingaan, Kuda Renggong, Angklung Buncis, and Debus are also included in this sub-sector.

\section{Computer or Software}

Computer services, data processing, database development, software development, system integration, system analysis and design, software architecture design, software and hardware infrastructure design, portal design, and maintenance are included in the creative sector of computer or software. Bandung regency has numerous creative people working in the computer or software sub-sector.

\section{Research and Development}

Research and development are the creative activities related to innovative ways and these provide society with new scientific or technological inventions and knowledge for new creative products, methods, and new technologies that can meet market needs. Bandung Regency has specialized research and development entities focusing on research and education consultancy.

Publishing and printing, crafts, advertising, art exhibitions, computer or software, and research and development are considered as the main potential of the creative economy in Bandung Regency. These six creative industries need to be focused because they have demonstrated their superiority, among others. There are four criteria for a creative sector to be considered as the progressive one, namely, 1) creation and copyright, 2) responses to markets, 3) development of active environments and 4) development of passive environments. Based on these four criteria, all sectors discussed above are considered mature because they have been proven to take part in the development of the economy. 


\section{Quadruple Helix}

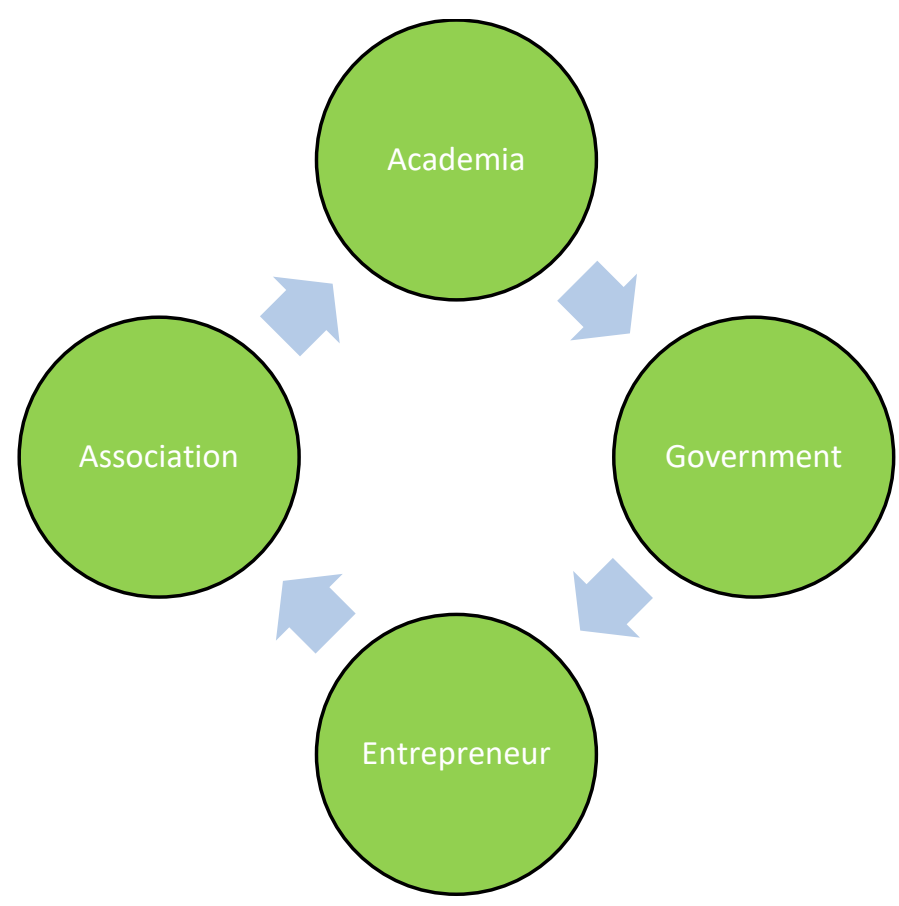

Figure 3. Quadruple Helix of Creative Industry in Bandung Regency

Table 1: Quadruple Helix of Creative Industry in Bandung Regency

\begin{tabular}{|c|c|c|c|}
\hline Strategy & Program & $\begin{array}{c}\text { Performance } \\
\text { Indicators }\end{array}$ & Output/Income \\
\hline \multirow[t]{3}{*}{$\begin{array}{l}\text { Strengthening the } \\
\text { partnership of } \\
\text { quadruple helix }\end{array}$} & $\begin{array}{l}\text { MoU between } \\
\text { government and } \\
\text { academia }\end{array}$ & $\begin{array}{l}\text { The ratio of creative } \\
\text { industry communities } \\
\text { which have MoU } \\
\text { with academia to } \\
\text { total creative } \\
\text { industries of } 10 \%\end{array}$ & $\begin{array}{l}50,000 \text { MoUs } \\
\text { between government } \\
\text { and academia }\end{array}$ \\
\hline & $\begin{array}{l}\text { MoU between } \\
\text { government and } \\
\text { associations }\end{array}$ & $\begin{array}{l}\text { The ratio of creative } \\
\text { industry associations } \\
\text { which have MoU } \\
\text { with the government } \\
\text { to total creative } \\
\text { industry associations } \\
\text { of } 100 \%\end{array}$ & $\begin{array}{l}\text { One MoU between } \\
\text { government and } \\
\text { associations }\end{array}$ \\
\hline & $\begin{array}{l}\text { MoU between } \\
\text { government and } \\
\text { businesses } \\
\text { (entrepreneurs) }\end{array}$ & $\begin{array}{l}\text { The ratio of creative } \\
\text { industry } \\
\text { entrepreneurs who } \\
\text { have MoU with the } \\
\text { government to total } \\
\text { creative industry } \\
\text { entrepreneurs of } 10 \%\end{array}$ & $\begin{array}{l}50,000 \mathrm{MoUs} \\
\text { between government } \\
\text { and entrepreneurs }\end{array}$ \\
\hline $\begin{array}{l}\text { Strengthening the } \\
\text { network of creative } \\
\text { industry } \\
\text { entrepreneurs }\end{array}$ & $\begin{array}{l}\text { MoU between } \\
\text { creative industry } \\
\text { entrepreneurs with }\end{array}$ & $\begin{array}{l}\text { The ratio of creative } \\
\text { industry } \\
\text { entrepreneurs who } \\
\text { have MoU with }\end{array}$ & $\begin{array}{l}50,000 \text { MoUs } \\
\text { between } \\
\text { entrepreneurs and }\end{array}$ \\
\hline
\end{tabular}

Copyright $\odot$ GLOBAL ACADEMIC EXCELLENCE (M) SDN BHD - All rights reserved 


\begin{tabular}{lll}
\hline $\begin{array}{l}\text { distributors/suppliers } \\
\text { of raw materials }\end{array}$ & $\begin{array}{l}\text { suppliers of raw } \\
\text { materials to total } \\
\text { creative industry } \\
\text { entrepreneurs of 10\% }\end{array}$ & $\begin{array}{l}\text { suppliers of raw } \\
\text { materials }\end{array}$ \\
\hline $\begin{array}{l}\text { MoU between } \\
\text { creative industry } \\
\text { entrepreneurs with } \\
\text { sellers/exporters }\end{array}$ & $\begin{array}{l}\text { The ratio of creative } \\
\text { industry } \\
\text { entrepreneurs who } \\
\text { have MoU with } \\
\text { exporters to total } \\
\text { creative industry } \\
\text { entrepreneurs of 10\% }\end{array}$ & $\begin{array}{l}\text { 50,000 MoUs } \\
\text { between } \\
\text { entrepreneurs and } \\
\text { exporters }\end{array}$ \\
& & \\
& & \\
\hline Steps & & \\
\hline Identification of academia, associations, and communities & \\
\hline Facilitating the producing of Quartet Helix MoUs \\
\hline Listing the types of MoUs
\end{tabular}

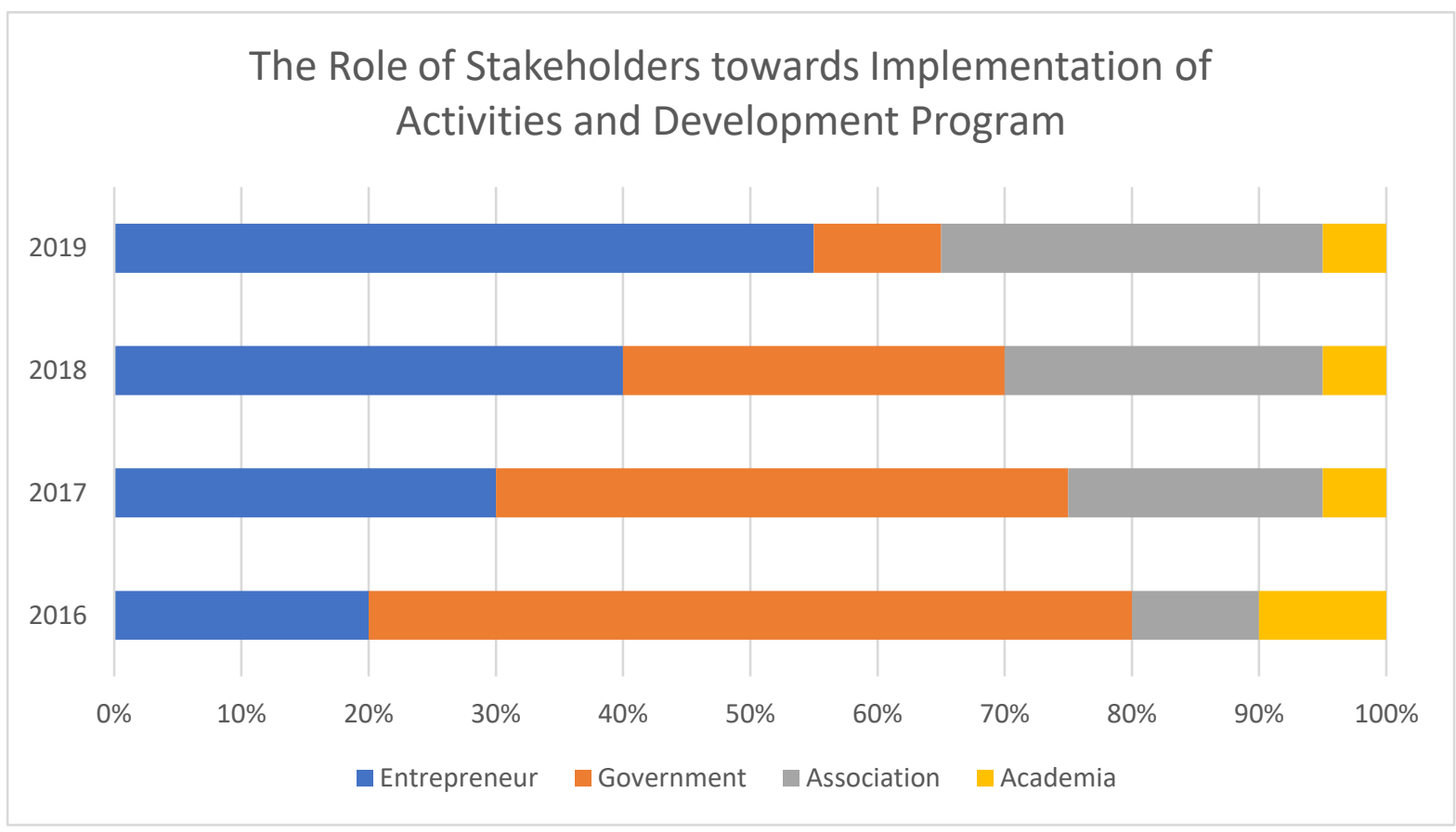

Figure 4. The Role of Stakeholders towards Implementation of Activities and Development Program

In the Quadruple Helix partnership, the role of government decreased from the level of 60 percent in 2016 to 10 percent in 2019. The decrease of government involvement was balanced by the developing creative industry entrepreneurs, reaching 55 percent in 2019. This phenomenon shows that the creative industry grows to be more independent every year.

\section{Government}

The government in this study, regarding the creative economy development plan, refers to the central government and regional or local governments related to the development of the creative economy. Those two entities may relate to both substantial and administrative matters. Local government includes regional government in level 1, level 2, and the lowest local 
government level. A good synergy between the central and local governments is needed to achieve the vision, mission, and goals of the development of creative industries. It happens because the development of the creative economy is not only industrial development but also includes the development of ideology, politics, society, and culture.

In the government of Bandung Regency, three service departments involve in developing the creative economy. They aim to facilitate and regulate the business development of the creative industries. These three service departments are the department of cooperatives, industry and trade (Diskoperindag), the department of youth, sports and tourism (Dispopar), and the department of agriculture, plantation and forestry (Distanbuthut).

\section{Association}

Associations or communities that support the development of the creative economy in Bandung Regency are already mature and developed. One of the most prominent communities is KABACA.

KABACA helps and absorbs all ideas and aspirations of creative entrepreneurs in Bandung Regency. To maximize the potential, KABACA conducts partnerships with the government, especially BAPPEDA (Agency for Regional Development).

Also, KABACA supports the development of creative economic policies. Furthermore, it acts as a place to discuss ideas or talent development and creative abilities. KABACA plays a role as an intermediary between creative entrepreneurs and the government. Besides, KABACA aims to encourage district governments in Bandung Regency to develop their industrial potential, as stated in INPRES No. 6 2009. Other roles of KABACA are; assisting the government in formulating creative economic development policies, formulating strategies and action plans as a reference for creative economy development, helping the government to reduce unemployment, increasing purchasing power, and increasing the human development index (HDI) and local income (PAD).

\section{Entrepreneur}

Entrepreneurs generate income as a result of their work. Business management is governed by the laws of where the business originates. The forms of business are sole proprietorship, partnership, corporation, and cooperative. A business can also be categorized based on the following sectors, namely, manufacturing, service, retail and distribution, agriculture, minerals, finance, information, real estate, transportation, and utilities such as electricity and irrigation which are usually associated with government agencies. Businesses have groupings of work or functions such as marketing, sales, production, information technology, research, and development. Management in business acts to help an organization to be more efficient and effective in its operations. Businesses may acquire capital from banks, informal creditors or investors. Businesses also need to be protected to prevent unfair business competition. Protection can be in the form of IPR (Intellectual Property Right) which includes patents, copyrights, trademarks, and designs.

All business entities have names, logos, and technical characteristics. Because of competition, businesses need to register the IPR in the countries where competitors are. Most countries have signed many IPR agreements. All companies must follow the country rules attached to the international agreement. Businesses can also be bought or sold. Business owners deal with it as an exit plan. The most prominent exit plans are an IPO (Initial Public Offering), merger, and acquisition. 


\section{Academia}

Academia has a significant reinforcement role in the basic formation of formal and informal innovation. Besides, it can mature innovation concepts and can disseminate information with international networks.

In Bandung Regency, the academia ready to support and assist the development of creative industries is Telkom University. Telkom University is one of the well-recognized universities possessing a study program of the creative economy. Partnerships between government and Telkom University are expected to create a more developed creative industry.

Other universities from outside the Bandung Regency also help the development of creative industries because of the closeness of culture and history. Universitas Pasundan and Universitas Padjadjaran are examples of the universities (located in Bandung city) assisting the government of Bandung Regency in developing the creative economy.

\section{SWOT Analysis}

Internal Factors Analysis Summary (IFAS) can help an organization to identify the strategic factors which play a role as strength and weakness in that organization. The results of the IFAS analysis of creative industries in Bandung Regency are shown as follows:

Table 2: Internal Factors Analysis Summary (IFAS)

\begin{tabular}{lccc}
\hline \multicolumn{1}{c}{ Internal Strategic Factor } & Value & Rating & Score \\
\hline A. Strengths & 0.13 & 4 & 0.52 \\
\hline Having varied products & 0.10 & 4.5 & 0.45 \\
\hline Distributors are spread across West Java province & 0.09 & 3.5 & 0.315 \\
\hline $\begin{array}{l}\text { Government is allowed to open investment credit as a } \\
\text { financing instrument }\end{array}$ & 0.15 & 5 & 0.75 \\
\hline $\begin{array}{l}\text { Prices of raw materials are affordable, and their } \\
\text { quantities are numerous }\end{array}$ & 0.07 & 3 & 0.21 \\
\hline Implementation of training and education & $\mathbf{0 . 5 4}$ & & $\mathbf{2 . 2 4}$ \\
\hline Total score of strengths (S) & & & \\
\hline B. Weaknesses & 0.07 & 3 & 0.21 \\
\hline $\begin{array}{l}\text { Poor promotion activities of creative industries in } \\
\text { printed mass media, television, and social media. }\end{array}$ & 0.12 & 2 & 0.24 \\
\hline Limited access to international market & 0.08 & 3 & 0.24 \\
\hline $\begin{array}{l}\text { Most of the entrepreneurs in creative industries are } \\
\text { only high school (SMA) graduates }\end{array}$ & 0.14 & 1.5 & 0.21 \\
\hline Lack of qualified human resources & 0.05 & 3.5 & 0.18 \\
\hline Prone to flood & $\mathbf{0 . 4 6}$ & & $\mathbf{1 . 0 8}$ \\
\hline Total score of weaknesses (W) & $\mathbf{1 . 0 0}$ & & $\mathbf{3 . 3 2}$ \\
\hline Total score (S+W) & &
\end{tabular}

\section{Strengths}

The first strength of creative industries in Bandung Regency is the various products produced by the business entities of this sector. Several goods and services offered to market include advertising service, architectural service, art or antique goods, crafts, computer or software, design, fashion, interactive games, and music. The second strength is the high number of distributors across West Java province. For clothing production, Bandung Regency is wellknown for its children's clothing, jackets, sandals, shoes, buckles, bags, and others. The 
distribution covers other cities in West Java province. The third strength is the easiness of getting government loans from banks. The loans can be used for financing the creative industries so they can produce quality products for the market. The fourth strength is the affordable price of raw materials. It is possible because of the strategic location of Bandung Regency. Thus, the availability of raw materials supports the operations of creative industries. Finally, the fifth strength of creative industries in Bandung Regency is the provision of training and education through programs such as Akademi Blusukan (university lecturers or professors mingle directly with society to solve problems) and the creative village of creative communities.

\section{Weaknesses}

Based on our study, we find that the first weakness of creative industries in Bandung Regency is the poor promotion activities of creative industries in several media such as printed media, television, and social media. As a consequence, many people are not aware of the products of the creative industries of Bandung Regency. The second weakness is the limited access to a global market and limited quantities to meet the minimum requirement of export. So far, the products are only sold in the domestic market. The third weakness relates to the drawback in the educational background of creative industry entrepreneurs. High school graduates of 515,133 labors dominate the total labor force. Those who have diploma degree are only 181,125 . The fourth weakness is the inadequate skills of the creative industry entrepreneurs, which is caused by the minimum contribution made by research and development division. The products are made using a traditional way. The last weakness of creative industries in Bandung Regency is they are prone to flooding, especially in the rainy season.

External Strategic Factors Summary (EFAS) can help a company to identify which strategic factors providing opportunities and threats to that organization. The results of EFAS analysis in creative industries in Bandung Regency are shown in the following table.

Table 3: External Factors Analysis Summary (EFAS)

\begin{tabular}{lccc}
\hline \multicolumn{1}{c}{ External Strategic Factor } & Value & Rating & Score \\
\hline A. Opportunities & & & \\
\hline $\begin{array}{l}\text { Regulation of INPRES No.6/2009 regarding Creative } \\
\text { Industry for supporting the creative economy in 2009- }\end{array}$ & 0.13 & 5 & 0.65 \\
$\begin{array}{l}2015 \\
\text { Richness of local wisdom }\end{array}$ & 0.11 & 4 & 0.44 \\
\hline The increasing number of populations & 0.07 & 3 & 0.21 \\
\hline The use of e-commerce technology & 0.15 & 5 & 0.75 \\
\hline The increasing interest rate & 0.09 & 4 & 0.36 \\
\hline Total score of opportunities (O) & $\mathbf{0 . 5 5}$ & & $\mathbf{2 . 4 1}$ \\
\hline B. Threats & & & \\
\hline Foreign products & 0.13 & 3 & 0.39 \\
\hline $\begin{array}{l}\text { The weakening Indonesian currency against USD in } \\
\text { 2018 }\end{array}$ & 0.11 & 3 & 0.33 \\
\hline Low morality level of Indonesian society & 0.07 & 2 & 0.14 \\
\hline Calamity & 0.09 & 2,5 & 0.22 \\
\hline Changing climate & 0.05 & 2 & 0.1 \\
\hline Total score of threats & $\mathbf{0 . 4 5}$ & & 1.18 \\
\hline Total Score (O+T) & $\mathbf{1}$ & $\mathbf{3 . 5 9}$ \\
\hline
\end{tabular}




\section{Opportunities}

We find that the regulation of INPRES No.6/2009 regarding the Creative Industry is the first opportunity of the creative economy in Bandung Regency. The development of economic activities emphasizing creativity, skills, and talents for creating valuable products will affect the welfare of Indonesian society. The second opportunity is the richness of local wisdom and cultures which become potential capital in the process of creativity and production of creative products. The third opportunity that can be utilized by creative industries in Bandung Regency is the increasing population. According to the Central Bureau of Statistics (BPS), the population of Bandung Regency was 3,596,623 in 2016 and 3,657,701 in 2017. This increase is an opportunity both in the market aspect and labor aspect. The fourth opportunity is ecommerce technology, which is growing and popular among society. Creative industry entrepreneurs should utilize it to develop their businesses. Finally, the fifth opportunity is the decrease in the interest rate. The interest rate in 2016 was $6.50 \%$, and in 2015 it was $7.50 \%$. This decrease gives easiness to the creative industry entrepreneurs to obtain a loan from banks.

\section{Threats}

The first threat faced by creative industries in Bandung Regency is foreign products. The competition with foreign products is tight since some people still perceive that imported products are more superior to the local ones. The second threat is the weakening Indonesian currency (rupiah) against the US dollar. Rupiah was traded at 13,548/USD in 2017 and down to $14,481 /$ USD in 2018. This condition resulted in increasing material costs and finally increased the product price. The third threat is the low morality of the Indonesian citizen. Many people in Indonesia still consider that a job or profession related to art is not promising. The fourth threat is calamity or disaster, which frequently happens in Bandung Regency. Bandung Regency is prone to flooding, and it will affect the production cost of the entrepreneurs. The last threat relates to the weather or climate. Presently, the weather cannot be predicted so the supply of raw materials and distribution process may be hampered.

\section{Conclusion}

The potential mapping of Bandung Regency shows that publishing and printing, handicrafts, advertisements, art exhibitions, computers or software, and research and development are the main sectors or focus to be developed. Quadruple helix connects four parties to work together and coordinate among others. It includes the work of government to facilitate and regulate business development of creative industries, the work of the association to support the development of creative economic policies, the work of entrepreneurs to generate financial income and encourage economic activities, and the work of academia to create innovations and concepts for ensuring creative industries to run smoothly. The strengths of the creative industries in Bandung Regency include the diversity of products, reliable distributor channel across West Java, loan access as financing instruments, affordable raw material price, and the provision of training and education.

Meanwhile, the weaknesses comprise the poor promotion of creative industries in most media, limited access to international markets, low educational background of the entrepreneurs, unskillful human resources, and floods. Based on EFAS analysis, the opportunities in creative industries in Bandung Regency include favorable regulation (INPRES No.6 / 2009 regarding Creative Industries), richness in local wisdom, increasing population, use of e-commerce technology, and decrease in interest rates. Also, the threats include competition from foreign products, the weak exchange rate of Rupiah against USD, low morality level of Indonesian people, natural disasters, and changing weather or climate. 
Theoretically, this study adds to the literature of management science, and this study serves as preliminary research for further studies regarding the strategic partnership model of creative industries. Practically, this study gives benefits to the creative industry entrepreneurs in terms of the strategic partnership model. This research has some limitations, and one of them is the limited sample, which is only from one city, namely, Bandung Regency. Thus, studies in other cities may have different results.

\section{Acknowledgments}

This research is funded and supported by Universitas Padjadjaran. Thus, we want to thank Universitas Padjadjaran and government Bandung Regency for all the help in conducting this research.

\section{References}

Boccella, N., \& Salerno, I. (2016). Creative Economy, Cultural Industries and Local Development. Procedia - Social and Behavioral Sciences, 223, 291-296. https://doi.org/10.1016/j.sbspro.2016.05.370

Calzada, I. (2016). Plugging smart cities with urban transfor mations: Towards multistakeholder city-regional complex urbanity. Journal of Urban Studies and Social Sciences, 6(2), 37.

Carayannis, E. G., \& Campbell, D. F. J. (2010). Triple helix, Quadruple helix and Quintuple helix and how do Knowledge, Innovation and the Environment relate to Each other? a proposed framework for a trans-disciplinary analysis of sustainable development and social ecology. International Journal of Social Ecology and Sustainable Development, 1(1), 41-69. https://doi.org/10.4018/jsesd.2010010105

Carayannis, E. G., Goletsis, Y., \& Grigoroudis, E. (2018). Composite innovation metrics: MCDA and the Quadruple Innovation Helix framework. Technological Forecasting and Social Change, 131, 4-17. https://doi.org/10.1016/j.techfore.2017.03.008

Colapinto, C., \& Porlezza, C. (2012). Innovation in Creative Industries: From the Quadruple Helix Model to the Systems Theory. Journal of the Knowledge Economy, 3(4), 343353. https://doi.org/10.1007/s13132-011-0051-x

Creative, O., \& Outlook, E. (2019). Opus creative economy outlook 2019.

Effendi, D., Syukri, F., Subiyanto, A. F., \& Utdityasan, R. N. (2016). Smart city Nusantara development through the application of Penta Helix model (A practical study to develop smart city based on local wisdom). 2016 International Conference on ICT for Smart Society, ICISS 2016, (July), 80-85. https://doi.org/10.1109/ICTSS.2016.7792856

Etzkowitz, H., \& Leydesdorff, L. (2000). The dynamic of innovation: from National System and "Mode 2" to a Triple Helix of university-industry-government relations, 109-123.

Etzkowitz, H., \& Zhou, C. (2007). The entrepreneurial University in Various Triple Helix Models.

Halibas, A. S., Sibayan, R. O., \& Maata, R. L. R. (2017). The penta helix model of innovation in Oman: An hei perspective. Interdisciplinary Journal of Information, Knowledge, and Management, 12, 159-172.

Hidayat, A. R. T., \& Asmara, A. Y. (2017). Creative industry in supporting economy growth in Indonesia: Perspective of regional innovation system. IOP Conf. Series: Earth and Environmental Science, 012031.

Kuswanto, F., Rosli, M. M., \& Kader, R. A. (2012). Innovation in Distribution Channel, Cost Efficiency \& Firm Performance: The Case of Indonesian Small \& Medium Enterprise Scales. International Journal of Business, Humanities and Technology, 2(4), 23-38.

Pol, H. Van Der. (2005). Key role of cultural and creative industries in the economy Introduction: Increasing role of cultural and creative industries. 
Ramesh Babu, G. (2008). Research Methodology in Social Sciences. Concept Publishing Company Pvt. Ltd., New Delhi, India.

Rosli, M. M., Raflis, A., \& Omar, C. (2012). Competitive Strategies and Firm Performance: A Comparative Study of Malaysian and Indonesian Small and Medium Enterprises. 3rd International Conference on Business and Economic

Rufaidah, P. (2014). Manajemen Strategik. Bandung: Humaniora.

Schütz, F., Heidingsfelder, M. L., \& Schraudner, M. (2019). Co-shaping the Future in Quadruple Helix Innovation Systems: Uncovering Public Preferences toward Participatory Research and Innovation. The Journal of Design, Economics, and Innovation, 5(2), 128-146. https://doi.org/10.1016/j.sheji.2019.04.002

UNCTAD, \& UNDP. (2008). Creative economy report - The challenge of assessing the creative economy: towards informed policymaking.

UNESCO. (n.d.). Understanding Creative Industries.

UNESCO, \& UNDP. (2013). Creative economy report - Widening local development pathways. 